\title{
İmalat Sektörü İşletmelerinin Nakit Akış Profillerinin İncelenmesi Ve Finansal Performanslarının TOPSIS Yöntemi İle Karşılaştırılması *
}

Türker AÇIKGÖZ**

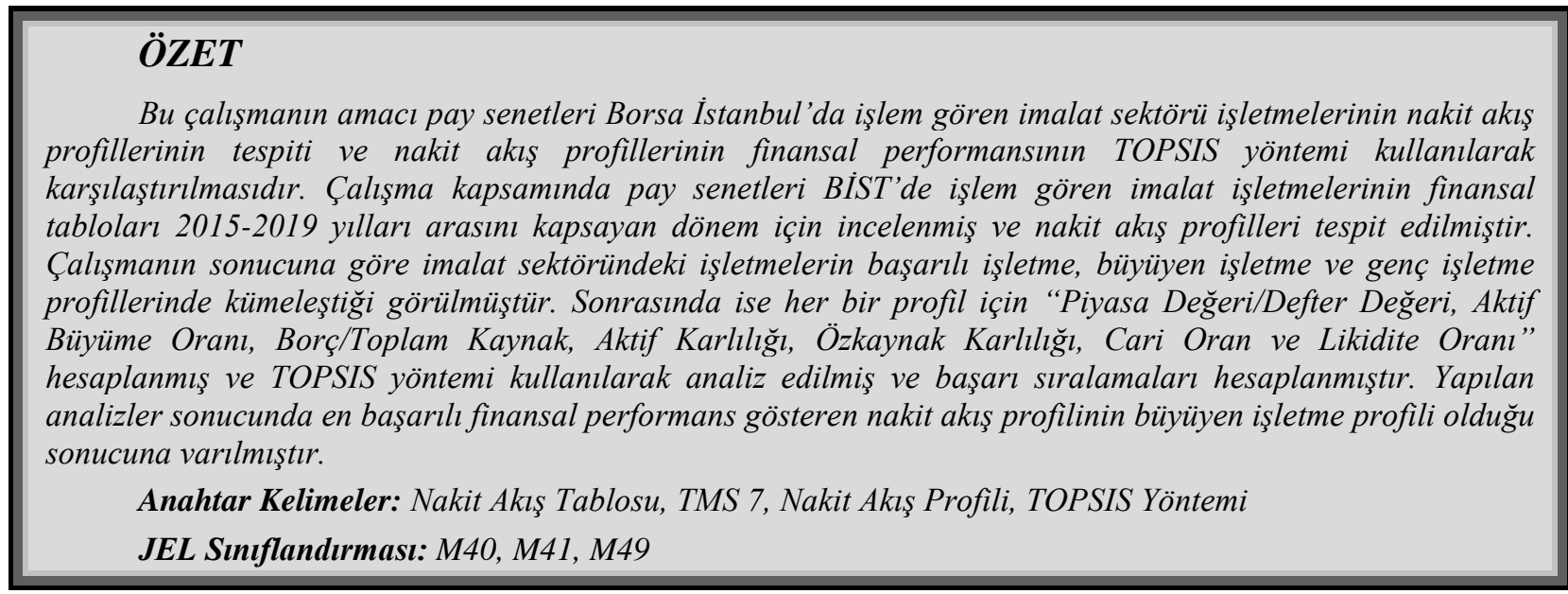

Investigation Of Cash Flow Profiles Of Manufacturing Sector And Comparison of Financial Performances with TOPSIS Method

\section{ABSTRACT}

The aim of this study is to determine the Cash Flow Profiles of the manufacturing sector enterprises whose stocks are traded in Istanbul Stock Exchange and to compare the financial performance of the Cash Flow Profiles by using TOPSIS Method. Within the scope of the study, the financial statements of the manufacturing enterprises whose stocks are traded on BIST were examined between 2015-2019 and their cash flow profiles were determined. According to the results of the study, it was observed that the enterprises in the manufacturing sector clustered in successful enterprise, growing enterpris and young enterprise profiles. Then, for each Cash Flow Profile "MV / BV, Asset Growth Ratio, Total Debt / Total Assets, Return on Assets, Return on Equity, Current Ratio and Liquidity Ratios" were calculated and analyzed by using TOPSIS Method and success rankings of profiles were calculated. As a result of the analysis, it was concluded that the cash flow profile with the most successful financial performance is the growing business (Profile 4) profile.

Keywords: Statement of Cash Flows, IAS 7, Cash Flow Profile, TOPSIS Method.

Jel Classification: M40, M41, M49

\footnotetext{
* Makale Gönderim Tarihi: 07.12.2020, Makale Kabul Tarihi: 03.02.2021 , Makale Türü: Nicel Araştırma

** Arş. Gör., Başkent Üniversitesi, İktisadi ve İdari Bilimler Fakültesi, turker.acikgoz1@gmail.com, ORCID: 0000-0002-5613-1929.
} 


\section{GİRIŞ}

Tam set finansal tablolardan birisi olan nakit akış tablosu günümüz işletmeleri için finansal raporlamalarının ayrılmaz bir parçası olmuştur. Tam set finansal tablolar içerisinde yer alan diğer finansal tablolardan en önemli farkı nakit esasına göre düzenlenmesidir. İşletmelerin yayınladıkları diğer finansal tablolar tahakkuk esasına göre düzenlenmekte iken nakit akış tablosunun nakit esasına göre düzenlenmesi işletme analizi için finansal bilgi kullanıcılarına büyük avantajlar sağlamaktadır. TMS 7- Nakit Akış Tablosu Standardı nakit akış bilgilerinin finansal bilgi kullanıcıları açısından önemini aşağıdaki sözlerle belirtmiştir.

"Nakit akış tablosu, diğer finansal tablolarla birlikte kullanıldığında, finansal tablo kullanıcılarının; işletmenin net varlıklarındaki değişimleri, işletmenin finansal yapısını (likidite durumu ve borç ödeme gücü dâhil) ve değişen koşullara ve firsatlara uyum sağlamak amacıyla nakit akışlarının tutarını ve zamanlamasını etkileme kabiliyetini değerlendirmesi için gerekli olan bilgileri sunar. Nakit akış bilgisi, işletmenin nakit ve nakit benzeri yaratma kabiliyetinin değerlendirilmesinde fayda sağlar ve kullanıcıların, farklı işletmelerin gelecekteki nakit akışlarının bugünkü değerini değerlendirmesi ve karşılaştırması için modeller geliştirmesine imkân tanır. Nakit akış bilgisi ayrıca, aynı işlem ve olaylara farklı muhasebe yöntemlerinin uygulanmasından kaynaklanan etkileri ortadan kaldırdığı için farklı işletmelerin faaliyet sonuçlarına ilişkin raporlamalarının karşılaştırılabilirliğini artırır.”

Nakit akışlarının kontrolü işletme yönetiminde en önemli unsurlardan birisidir. Tahakkuk esasının bir ürünü olan kar kavramıyla kıyaslandığında finansal bilgi kullanıcılarına işletmeye farklı bir açıdan bakma imkânı sağlamaktadır. Çünkü tahakkuk esasına göre oluşturulan kar kavramı bazen yanıltıcı olabilmektedir. Faaliyet dönemi içerisinde görece yüksek bir karlılık düzeyine ulaşmış bir işletmenin esasen nakit akışları problemli olabilir. Nakit çıkışı gerektiren bir işlemin yaklaşması fakat işletmenin nakit darlığı içerisinde olmasıyla ödemelerini gerçekleştirememesi durumunda karlılığın pek bir anlamı kalmamaktadır. Bu durumdaki bir işletme eğer yeni bir finansman kaynağı bulamaz ise iflas riskiyle karşı karşıya kalması yüksek olasılık dahilindedir.

Yukarıda tanımlanan durumun işletmecilik tarihinde örneklerine sıkça rastlanmaktadır (Largay ve Stickney, 1980). Geçmiş yıl finansal performanslarına bakıldığında karlılığı ve likiditesi yüksek görünen işletmelerin nakit akışı üretememesi veya nakit yönetiminde başarısızlık sergilemesi işletme iflasına sebebiyet veren en önemli unsurlardan olmuştur. $\mathrm{Bu}$ sebeple işletmelerin analizinde yalnızca tahakkuk esasına göre düzenlenen finansal durum tablosu ve kapsamlı gelir tablosu değil, nakit esasına göre düzenlenen nakit akış tablosu da kullanılması daha gerçekçi sonuçlara ulaşmak açısından önemlidir.

Literatürde nakit akış tablolarının analizi üzerine yapılmış olan çalışmalar incelendiğinde temelde iki yöntem neredeyse tüm literatürü kapsamaktadır. Bunlar "Nakit Akış Oranları" ve "Nakit Akış Profili" yöntemidir. Nakit akış oranları yöntemi nakit akış tablosundan elde edilen bilgilerin oranlama yöntemiyle geliştirilen finansal oranların kullanılmasıdır. Geleneksel finansal oranlara alternatif olarak kullanılmaktadır. Literatürde sıkça kullanılan ve bu çalışmanın da konusunu oluşturan diğer yöntem ise "Nakit Akış Profili" yöntemidir. Bu yöntem ise işletmenin nakit akışlarını sağladığı üç ana faaliyetin; işletme, yatırım ve finansman faaliyetlerinden nakit akışlarının işaretlerinin 
kombinasyonlarına göre 8 işletme profili oluşturmak suretiyle işletmeleri analiz eden bir nakit akış tablosu analiz yöntemidir.

$\mathrm{Bu}$ çalışmada yukarıda anlatılan "Nakit Akış Profili" yöntemi kullanılarak pay senetleri Borsa İstanbul'da işlem gören imalat sektörü işletmelerinin 2015-2019 yılları için nakit akış profilleri belirlenmiştir. Daha sonrasında ise belirlenen nakit akış profilleri belirli finansal göstergeler kullanılarak TOPSIS (Technique for Order Preference by Similarity to Ideal Solutions) Yöntemi ile analiz edilmiş, nakit akış profili yöntemine göre belirlenen işletme profillerinin finansal performansları karşılaştırılmıştır. Böylece hem nakit akış profili yönteminde bahsedilen işletme profillerinin tutarlılığ 1 test edilmiş, hem de bu profiller arasında finansal performansın nasıl değiştiği ortaya konulmaya çalışılmıştır.

\section{TEORIKK ARKA PLAN VE LITERATÜR TARAMASI}

\subsection{Kavramsal Çerçeve}

Gup ve diğ. (1993) yaptıkları çalışmada Amerikan Birleşik Devletleri’nin halka açık en büyük 1725 şirketinin nakit akış tablolarını incelemişlerdir. Bu çalışmalarında nakit akış tablolarının analizi için yeni bir yöntem geliştirmişlerdir. Nakit akış tablosu; "İşletme Faaliyetlerinden Nakit Akışları (İFNA), Yatırım Faaliyetlerinden Nakit Akışları (YFNA) ve Finansman Faaliyetlerinden Nakit Akışları (FFNA)" olmak üzere 3 ana bileşenden oluşmaktadır. Gup ve diğ. (1993) nakit akış tablosunun bileşenlerinin alabilecekleri işaretlerin (pozitif veya negatif olma durumuna) muhtemel 8 kombinasyon için işletmelerin 8 profile sahip olduklarını öne sürmüşlerdir. Yapmış oldukları çalışmada analiz ettikleri 1.725 işletmeyi nakit akışlarının işaretleri ve bu işaretlerin kombinasyonları açısından sekiz gruba ayırmışlardır. Daha sonrasında ise bu gruplarda kümelenmiş işletmeleri; "Aktif Büyüklügüü, Aktif Büyümesi, İç Büyüme Oranı, Temettü Büyüme Oranı, Borç/Aktif Toplamı ve Aktif Karlılığı” ölçütlerini kullanarak incelemişlerdir. Yapılan incelemeler sonucunda nakit akışlarının işaretlerinin kombinasyonlarından oluşturdukları grupların belirli karakteristik özellikleri olduğu tespit edilmiş ve bu gruplara birer "Profil" adı verilerek sinıflandırılmıştır. Gup ve diğ. (1993) yaptıkları bu çalışmanın sonucunda işletmelerin nakit akışlarının işaretlerine göre oluşturdukları 8 işletme profili ve bu profiller içerisinde yer alan işletmelerin belirgin özelliklerine ait çıkarımlar aşağıdaki gibidir.

Tablo 1. Nakit Akış Profilleri

\begin{tabular}{|c|l|c|c|c|}
\hline Profiller & \multicolumn{1}{|c|}{ Tanım } & IFNA & YFNA & FFNA \\
\hline Profil 1 & Nadir Durum & + & + & + \\
\hline Profil 2 & Başarılı İşletme & + & - & - \\
\hline Profil 3 & Gerileyen veya Yeniden Yapılanan İşletme & + & + & - \\
\hline Profil 4 & Büyüyen İşletme & + & - & + \\
\hline Profil 5 & Küçülen İşletme & - & + & + \\
\hline Profil 6 & Genç İşletme & - & - & + \\
\hline Profil 7 & Likiditasyona Giden İşletme & - & + & - \\
\hline Profil 8 & Nadir Durum & - & - & - \\
\hline
\end{tabular}


Profil $1(+,+,+)$ : Bu grupta sınıflandırılan işletmeler; işletme, yatırım ve finansman faaliyetlerinin tamamından pozitif nakit akışı sağlamaktadır. İşletme başarılı bir şekilde esas faaliyetlerinden pozitif nakit akışı üretirken aynı zamanda duran varlıklarını ve uzun vadeli yatırımlarını elden çıkarmakta ve devamlı sermayesinde artışa gitmektedir. Nadir durum olarak adlandırılan bu durum sürdürülebilir değildir. Nakit akış profili bu nadir durumu sergileyen işletmelerin yakın bir zamanda pay geri alma, uzun vadeli borçlarını kapatma (örn. tahvil geri çağırma) veya işletme satın almaya hazırlanıyor olma ihtimali yüksektir.

Profil 2 (+,-,-): "Başarılı İşletme” olarak tanımlanan, en yaygın olan nakit akış profilidir. İşletme esas faaliyetinden pozitif nakit girişi sağlamakta ve bununla yatırım faaliyetlerini, borç anapara ve faiz ödemeleri ile temettü ödemelerini gerçekleştirmektedir. $\mathrm{Bu}$ nakit akış profili genellikle olgun, başarılı ve stabil bir büyüme gösteren işletmelerde oluşmaktadır.

Profil 3 (+,+,-): “Gerileyen veya Yeniden Yapılanmaya Giden İşletme” profili olarak tanımlanan profil 3'de işletme esas faaliyetinden pozitif nakit akışı yaratmakta fakat aynı zamanda uzun vadeli yatırımlarını da satmaktadır. Finansman faaliyetlerinden nakit akışlarının negatif olması durumu da göz önüne alındığında işletmenin esas faaliyetlerinden elde ettiği nakit akışlarının borç anapara ve faiz ödemelerine, temettü ödemelerine, finansal kiralama işlemlerine yetmediği, bu sebeple duran varlıkların satışından nakit girişi sağlaması muhtemeldir. Bu profil de profil 1 gibi çok sık rastlanmayan bir durumdur. Çünkü işletme kreditörlerine ve ortaklarına ödemelerini karşılamak için nakit üreten birimlerinin satışını gerçekleştirmektedir. Bu durum işletmenin sürekliliği kavramı göz önünde tutulduğunda işletme likiditasyona gitmediği sürece süreklilik arz edemeyecek bir durumdur.

Profil $4(+,-,+)$ : “Büyüyen İşletme” profilidir. İşletme esas faaliyetinden ve finansman faaliyetlerinden pozitif nakit akışı sağlamakta, yatırım faaliyetlerinden ise negatif nakit akışı oluşmaktadır. Bu profildeki işletmelerin esas faaliyetlerinden elde ettikleri pozitif nakit akışının yatırım faaliyetlerini karşılamaya yetmemekte, bu sebeple dış finansmana ihtiyaç duymaktadırlar. Bu sebeple profilin büyüyen işletmeleri yansıttığı düşünülmektedir.

Profil $5(-,+,+)$ : “Küçülen İşletme” profili olarak adlandırılmaktadır. Pek sık görülmemekle birlikte işletme esas faaliyetinden negatif, yatırım ve finansman faaliyetinden ise pozitif nakit akışı yaratmaktadır. İşletme esas faaliyetlerinde başarısız performans sergilemekte, sonucunda ise negatif nakit akışı oluşmaktadır. Bu açığın finansmanı ise duran varlıkların satımı ve yeni finansman kaynakları ile sağlanmaktadır. İşletme duran varlıklarını satış yoluyla azaltması sebebiyle büyüme oranları düşüş gösterecektir. Halihazırda esas faaliyetlerinden nakit elde edemeyen, duran varlıklarının satışı sebebiyle kendisini daha zor bir duruma sokan işletme, sonraki faaliyet döneminde operasyonel faaliyetlerinde daha da kötü performans gösterecektir. Tekrardan işletme faaliyetlerindeki negatif nakit akışını finanse etmekte aynı yola başvuracak ve bir kısır döngüye girecektir. Bu sebeple profil, küçülen işletme profili olarak adlandırılmıştır.

Profil 6 (-,-,+): “Genç İşletme” profili olarak adlandırılmaktadır. Bu gruptaki işletmeler esas faaliyetlerinden ve yatırım faaliyetlerinden negatif, finansman faaliyetlerinden ise pozitif nakit akışı sağlamış işletmelerdir. İşletme faaliyetlerinden ve yatırım faaliyetlerinden negatif nakit akışları tamamen veya kısmen dış finansman kaynaklarıyla karşılanmaktadır. Esas faaliyetlerinden negatif nakit akışı yaratılmasının geçici bir durum 
olduğu düşünülmektedir. Çünkü işletme aynı zamanda duran varlık yatırımları gerçekleştirmektedir. Yakın bir zamanda işletmenin yaptığı duran varlık yatırımları nakit üretmeye başlayacak ve işletme faaliyetlerinden nakit akışları pozitife dönmeye başlayacaktır. Ayrıca işletme faaliyetlerinden nakit akışlarının negatif olması hızla artan satışlara paralel olarak çalışma sermayesine yapılan yatırımlar ve kısa vadeli borçların ödenmesinden kaynaklı olabilir. $\mathrm{Bu}$ sebepler ile bu profilde yer alan işletmelerin genç işletmeler olduğu öne sürülmüştür.

Profil 7 (-,+,-): “Likiditasyona Giden İşletme” profilidir. Bu profildeki işletmeler işletme ve finansman faaliyetlerinden negatif nakit akışı, yatırım faaliyetlerinden ise pozitif nakit akışı sağlamaktadırlar. İşletme esas faaliyetlerinden negatif nakit akışı yaratmakla birlikte aynı zamanda kreditörleri ve pay sahiplerine kaynak aktarımı sebebiyle nakit birikimi erimektedir. Esas faaliyetlerinden nakit üretmesinin aracı olan duran varlıklarını satarak işletme kreditörleri ve pay sahiplerini fonlamakta ve operasyonel kapasitesini azalmaktadır. $\mathrm{Bu}$ sebeplerle bahsi geçen profil likiditasyona giden işletme profili olarak adlandırılmıştır. $\mathrm{Bu}$ durumun belirli bir süre devam etmesi işletmenin likiditasyonu ile sonuçlanması muhtemeldir.

Profil 8 (-,-,-): “Nadir Durum” olarak adlandırılmaktadır. İşletme nakit akışı yarattığı tüm aktivitelerinden; işletme, yatırım ve finansman faaliyetlerinden negatif nakit akışı yaratmaktadır. $\mathrm{Bu}$ durumda işletme duran varlık satın alırken aynı zamanda kreditörlere ödeme yapmaktadır. Fakat esas faaliyetlerinden nakit üretemediği, aksine nakit tükettiği için işletme tüm faaliyetlerinin finansmanında geçmiş yıllarda birikmiş nakit stokları kullanılmaktadır. Pek sık karşılaşılan bir durum olmamakla birlikte bu profildeki işletmelerin uzun süre boyunca bu durumu sürdürmeleri mümkün değildir.

\subsection{Literatür Taraması}

Literatürde Borsa İstanbul'da faaliyet gösteren işletmelerin nakit akış profillerini inceleyen birçok çalışma bulunmaktadır. Bu çalışmalar ve nakit akışı profili yönteminin gelişmesinde önemli uluslararası çalışmalar aşağıda verilmiştir.

Steyn-Bruwer ve Hamman (2005) yaptıkları çalışmada, Gup ve diğg. (1993) tarafindan ortaya konulan nakit akış profili yöntemini geliştirmişler ve yaşam döngüsü teorisi ile birlikte ele almışlardır. Steyn-Bruwer ve Hamman (2005) yaptıkları çalışmada Güney Afrika imalat işletmelerinin nakit akış profillerini incelemiş ve en sık rastlanan işletme profillerinin sırasıyla başarılı işletme (profil 2), büyüyen işletme (profil 4) ve genç işletme (profil 6) profiller olduğunu saptamışlardır.

Dickinson (2011) tarafından yapılan çalışmada, Gup ve diğ. (1993) tarafindan geliştirilen nakit akış profili yöntemini kullanarak firma yaşam döngüsü teorisini geliştirmiştir. Çalışma kapsamında halka açık ve piyasa değeri 1 milyon ABD Doları'nın üzerinde olan Amerikan şirketleri 1989-2005 yılları arasını kapsayan dönem için incelenmiş, 48.369 firma-yıl gözlem verisi kullanılmıştır. Çalışma sonucunda Dickinson (2011) firma yaşam döngüsü çalışmalarında analizlerin işletme büyüklüğü, karlılık, firma yaşı gibi tek değişkene bağlı olarak ölçülmesinin yanıltıcı sonuç verebileceğini, bu sebeple nakit akış profili yöntemiyle birlikte kullanılması gerektiğini savunmuştur. Böylece daha gerçekçi sonuçlara ulaşılacağını belirtmiş̧tir. 
Karğın ve Aktaş (2011) yaptıkları çalışmada, Borsa İstanbul'da işlem gören halka açık bir inşaat işletmesinin 2006-2010 yıllarını kapsayan nakit akış tablolarını incelemiştir. Karşılaştırmalı tablolar analizi, eğilim yüzdeleri analizi, finansal oran analizi ve nakit akışlarının sağlandığı faaliyetler yöntemini kullanmışlardır. Analiz sonucunda nakit akışlarının sağlandığı faaliyetler yönteminin diğer analiz teknikleri ile birlikte kullanıldığında, işletmelerinin ekonomik durumlarının analizinde daha detaylı ve faydalı sonuçlar doğurduğu ortaya konulmuştur.

Aktaş ve diğ. (2012), halka açık 176 işletme üzerinde yaptıkları çalışmada, nakit akışlarının sağlandığı faaliyetler yöntemini kullanmış ve analiz işletmelerin bulunduğu sektör, yıl ve aktif büyüklükleri temelinde yapılmıştır. Yapılan çalışma ile işletmelerin profil 2, profil 3 ve profil 6 profillerinde yer alan işletme profillerinde yoğunlaştıği gözlemlenmiştir.

Orhan ve Başar (2015) tarafından, 2008-2013 yılları arasında BİST 100 endeksinde işlem gören 55 işletme incelenerek nakit akış profilleri saptanmış ve seçilen finansal oranlar ile karşılaştırılmıştır. Saptamalar sonucunda işletmelerin ağırlıklı olarak profil 2, profil 4 ve profil 6 kategorisi altında bulundukları gözlemlenmiştir. Her profilde yer alan işletmeler için aktif toplamı, aktif büyümesi, net kar büyümesi, borç/kaynak oranı, aktif karlılığı ve özkaynak karlılığ 1 bilgileri toplanmıştır. İşletmeler profillere dağıtıldıktan sonra bu finansal bilgilerin ortalamaları alınarak her profilin finansal oranları saptanmıştır. Daha sonrasında profil 2 baz alınarak profiller arasında bu finansal göstergeler açısından anlamlı bir fark olup olmadığı test edilmiştir. Aktif büyüklüğü açısından profil 3-6-8, net kar büyüme, aktif karlılığı ve özkaynak karlılığ 1 açısından profil 4, borç/kaynak oranı açısından ise profil 4-6-8'de istatistiki açıdan profil 2 ile anlamlı fark saptanmıştır. Aktif büyüme oranında ise herhangi bir profil ile anlamlı bir fark saptanmamıştır.

Karadeniz (2017) yaptığı çalışmada Amerika kıtasından 25, Avrupa kıtasında 51 ve Asya-Pasifik kıtasından 131 olmak üzere toplamda 207 halka açık konaklama şirketinin nakit akış tablolarını yıl, kıta ve Türkiye temelinde, nakit akışlarının sağlandığı faaliyetler yöntemine göre analiz etmiştir. Yapılan analizler sonucunda incelenen halka açık konaklama şirketlerinin hem kıtalar hem de Türkiye özelinde profil 2, profil 4 ve profil 3 gruplarında yoğunlaştı̆̆ saptanmıştır.

Kepçe (2017) tarafindan gerçekleştirilmiş olan çalışmada işletmelerin ekonomik özelliklerinin değerlendirilmesinde nakit akış tablosu bilgilerinin kullanılabilirliği analiz edilmiştir. Çalışma kapsamında pay senetleri BİST 100 endeksinde işlem gören imalat sektörü işletmelerinin 2011-2015 yıllarını kapsayan döneme ilişkin nakit akış profilleri çıkarılmıştır. Analizler sonucunda hâkim işletme profillerinin sırasıyla başarılı işletme (profil 2), büyüyen işletme (profil 4) ve genç işletme (profil 6) olduğu görülmüştür. İşletmelerin nakit akış profillerinin yanı sıra aktif büyüklügüu, büyüme oran1, kaldıraç oranı, aktif karlılığı ve özkaynak karlılığı da hesaplanmış olup işletme profilleri ile Kendal's Tau-b Korelasyon yöntemi kullanılarak nakit akış profilleri ile finansal oranlar arasındaki ilişki incelenmiştir. Çalışmanın sonucunda işletmelerin nakit akış profillerini kullanarak işletmelerin finansal durumunu karakterize etmenin doğru sonuçlar veremeyeceği belirtilmiştir.

Karadeniz ve diğ. (2018) yaptıkları çalışma ile dünyada 32 ülkede faaliyet gösteren 244 restoran işletmesinin 5 yıllık nakit akışlarını inceleyerek, nakit akışlarının sağlandığı faaliyetler yöntemine göre ait oldukları profiller ve işletmelerin firma yaşam döngüsü 
bakımından durumları tespit edilmiştir. Yapılan analiz sonucunda işletmelerin başarılı işletme (Profil 2) grubunda yoğunlaştıkları ve firma yaşam döngüsünde olgunluk ve büyüme evrelerinde seyrettikleri gözlemlenmiştir.

Baskan ve Dozen (2019) çalışmalarında BİST 100 endeksinde yer alan finans sektörü dışı 50 işletmelerin nakit akış tablolarını 2009-2018 yılları arası için incelemiştir. Öncelikle nakit akış profili tespit edilen işletmelerin büyük çoğunluğunun başarılı işletme (profil 2) ve büyüyen işletme (profil 4) grubunda oldukları saptanmıştır. Ardından ise en sık görülen başarılı işletme profiline sahip olmanın belirleyicilerini tespit etmek amacıyla nakit akış oranları kullanılarak Basit Lojistik Regresyon yöntemiyle analiz yapılmıştır. Yapılan çalışma sonucunda işletmelerin kar kalitesi ve nakit akış likiditesi oranları ile başarılı işletme profiline sahip olunması arasında anlamlı bir ilişskinin varlığına rastlanamamıştır. Buna karşın varlıkların nakit getirileri ile özkaynak getirisi değişkenlerinin başarılı işletme profiline sahip olunması arasında istatistiki açıdan anlamlı bir ilişki tespit edilmiştir.

Beyazgül ve Karadeniz (2019) futbol kulüplerinin nakit akış performansları üzerine yaptıkları çalışmalarda, Türkiye Spor Toto Süper Ligi ve Avrupa'da yer alan 10 ulusal ligde bulunan 29 futbol kulübünün nakit akışlarını incelemişlerdir. Nakit akışlarının sağlandığı faaliyetler yöntemi ile yapılan analiz sonuçlarına göre Avrupa'da yer alan futbol kulüplerinin nakit akış profilleri, profil 2 üzerinde yoğunlaşırken, Türkiye'de bulunan futbol kulüplerinin profil 6 üzerinde yoğunlaştığı gözlemlenmiştir.

Tüfekçi ve Karaca (2019) Fortune 500 listesinde yer alan en yüksek net satış hasılatına sahip olan 50 ulusal ve 50 uluslararası olmak üzere toplamda 100 işletme üzerinde yaptığ1 çalışma ile nakit akışlarının sağlandığı faaliyetler yöntemi ile oran analizi yöntemini birlikte kullanarak işletmelerin mevcut ve gelecekteki durumları ile ilgili bilgiler edinmeyi amaçlamıştır. Çalışma kapsamında 2010-2016 yılları arası incelenmiştir. Yapılan çalışma sonucunda hem ulusal hem de uluslararası işletmelerin, başarılı işletme (profil 2) ve büyüyen işletme (profil 4) grubunda yoğunlaştıkları gözlemlenmiştir. Ulusal şirketler arasında en yüksek üçüncü grup genç işletmeler (profil 6) olmasına karşın uluslararası işletmelerde bu profile rastlanmamıştır. Daha sonrasında 14 adet nakit akış oranı ile tüm dönemlerde: başarılı işletme (profil 2) grubunda yer almış 15 işletme analiz edilmiştir. Bu işletmelerin esas faaliyetlerinden elde ettikleri nakit akışlarının faaliyetlerini başarıyla sürdürmelerinde yeterli olduğu sonucuna varılmıştır.

Kablan ve Güvemli (2019) BİST kapsamında işlem gören turizm işletmelerinin nakit akış profillerini incelemişlerdir. Ara dönem finansal tabloları kullanılarak yapılan çalışmada 2012-2016 yılları arası incelenmiştir. Yapılan çalışma sonucunda BİST bünyesinde işlem gören turizm işletmelerinin nakit akış profillerinin sirasıyla, başarılı işletme (profil 2), büyüyen işletme (profil 4) ve genç işletme (profil 6) gruplarında yoğunlaştığı sonucuna varmışlardır.

Güleç ve Arda (2019) yaptıkları çalışmada BİST kapsamında işlem gören ve finansal olmayan 206 işletmenin 2008-2017 yılları arasını kapsayan döneme ilişkin nakit akış tablolarını kullanarak nakit akış profillerinin analizini gerçekleştirmişlerdir. Yapılan çalışma sonucunda örneklemin büyük çoğunluğunun başarılı işletme (profil 2) ve büyüyen işletme (profil 4) gruplarında oldukları tespit edilmiştir. Sektör bazına inildiğinde ise en baskın profillerin; İmalat, Ulaştırma Depolama ve Haberleşme, Teknoloji ile Toptan ve Perakende 
Ticaret, Lokantalar ve Oteller sektörlerinin tamamında sırasıyla başarılı işletme, büyüyen işletme ve genç işletme profilleri olmuştur.

Cavlak ve Yılmaz (2020) yaptıkları çalışmada BİST Sürdürülebilirlik Endeksi'nde yer alan 46 işletmenin nakit akış yapıları ile finansal sıkıntı durumlarını birlikte analiz etmek suretiyle incelemişlerdir. Böylece işletmelerin finansal sıkıntı durumları ile nakit akış yapılarının uyuşup uyuşmadığı test edilmiştir. Çalışma kapsamında nakit akışlarının yapısını incelemede nakit akış profili yöntemi kullanılmıştır. Finansal sıkıntının incelenmesinde ise işletmelerin Altman Z skoru kullanılmıştır. Yapılan analizler sonucunda işletmelerin büyük çoğunluğunun başarılı işletme profiline (profil 2) sahip olduğu, yıllar itibariyle başarılı işletme sayısında düşüş görülse de toplam içerisinde başarılı işletme profiline sahip işletmelerin sayısının 54\%'ün altına düşmediği gözlemlenmiştir. Başarılı işletme profilinden sonra en sık görülen işletme profili ise büyüyen işletme (profil 4) profili olmuştur. İşletmelerin finansal sıkıntı durumları ile nakit akış profillerinin birlikte analizi sonucunda başarılı işletme profiline sahip şirketlerin çoğunluğunun finansal sıkıntı alanı dışında olduğu, buna karşın gerileyen veya yeniden yapılanmaya giden işletme (profil 3), küçülen işletme (profil 5) ve genç işletmelerin (profil 6) finansal sıkıntı alanında yer aldıkları tespit edilmiş̧ir.

Kablan ve Altun (2020) tarafından yapılan çalışmada İstanbul iline bağlı ilçe belediyelerinin 2014-2018 dönemlerine ait 445 adet faaliyet raporunun içeriği nakit akış tablosu özelinde incelenmiş ve İstanbul Büyükşehir Belediyesi'ne bağlı Beylikdüzü Belediyesi ve Beyoğlu Belediyesi'ne ait 2017-2019 dönemlerini kapsayan nakit akış tabloları nakit akış profili yöntemi ile nakit akış oranları kullanılarak analiz edilmiştir. Analiz sonucunda Beylikdüzü Belediyesi'nin tüm yıllar için büyüyen belediye (profil 4), Beyoğlu Belediyesi'nin ise tüm yıllar için genç belediye (profil 6) grubunda oldukları sonucuna ulaşılmıştır.

\section{ARAŞTIRMANIN KAPSAMI VE TASARIMI}

\subsection{Araştırmanın Amacı ve Kapsamı}

$\mathrm{Bu}$ çalışmanın amacı, pay senetleri Borsa İstanbul (BİST)'da işlem gören imalat sektörü işletmelerinin 2015-2019 yıllarını kapsayan döneme ait nakit akış profillerini ortaya çıkarmak ve belirli finansal göstergeler ile nakit akış profilleri karşılaştırmaktır. Bu amaçla işletmeler, Gup ve diğ. (1993) tarafından ortaya konan nakit akış profillerine göre ile sekiz profile dağıtılmıştır. Sonrasında ise bu profillerde yer alan işletmelerin finansal göstergeleri hesaplanmış ve her profilin finansal göstergelerinin ortalama değerleri ortaya konmuştur. Son olarak bu ortalama değerler kullanılarak, Çok kriterli karar verme yöntemlerinden birisi olan TOPSIS Yöntemi ile analiz edilmiş ve 8 profil birbiriyle karşılaştırarak sıralamaya tabii tutulmuş, hangi profilde yer alan işletmelerin daha üstün finansal performans gösterdiğine bakılmıştır. Böylece, kısmen de olsa, Gup ve diğ. (2003) Steyrn-Bruwer-Hamman (2005) ve Dickinson (2011) tarafindan geliştirilmiş olan ve Türkiye'de literatürde kendisine çokça yer bulan "Nakit Akış Profilli" yönteminin tutarlılığı test edilmiştir.

\subsection{Veri Seti}

Çalışma kapsamında Borsa İstanbul'da pay senedi işlem gören imalat sektörü şirketleri analiz edilmiştir. Verilerin toplandığı tarih olan Mayıs 2020 itibariyle BİST'de payları işlem 
gören imalat sektörü işletmesi sayısı 171'dir. Bu 171 işletmenin 2015-2019 yılları arasındaki 5 yıllık nakit akış tabloları ve dipnotları vasıtasıyla işletme, yatırım ve finansman faaliyetlerinden nakit akışları bilgileri toplanmış ve analize uygun halde bir araya getirilmiştir. Çalışmanın beş yıllık bir dönemi kapsaması sebebiyle, analizlerin bütüncüllüğünü bozmaması adına nakit akış tabloları son beş yıl boyunca aralıksız yayınlanmış işletmeler analize dahil edilmiştir. Herhangi bir yıl için nakit akış tablosu yayınlanmamış işletmeler çalışma dışı tutulmuştur.

Nakit akış profili yöntemi işletmeleri nakit akışlarının pozitif veya negatif olma durumuna göre 8 profile ayıran bir yöntemdir. Bu yöntemin uygulanması için işletmelerin işletme, yatırım ve finansman faaliyetlerinden nakit akışları kalemlerinde nakit giriş ve/veya çıkış işlemleri gerçekleşmesi gerekmektedir (Gup ve dĭ̆., 1993, ss.3). Diğger bir deyişle yöntemin doğru sonuç vermesi için işletmelerin cari dönem için bu 3 faaliyet kolunda da bir aktivite gerçekleşmiş olması gerekmektedir. Veri toplama aşamasında bazı işletmelerin, nakit akış tablosunu oluşturan üç ana başlıktan birisinde herhangi bir faaliyet göstermediği görülmüştür. Bazı işletmeler yatırım, bazı işletmeler ise finansman faaliyetlerinden herhangi bir nakit giriş veya çıkışı gerçekleştirmemiş, bu faaliyetlerde ilgili yılda pasif kalmıştır. Bunun sonucu olarak üç ana nakit akışı başlığından birisi sıfır olan işletmelere denk gelinmiştir. Ayrıca nakit akış profili yöntemini ortaya koyan çalışma incelendiğinde işletmelerin, işletme, yatırım ve finansman faaliyetlerinden nakit akışlarının işaretine göre profilleri çıkarılmaktadır. Yöntemin anlamlı olabilmesi için ana başlıkların pozitif veya negatif olması gerekmektedir. Matematik bilimi incelendiğinde, sıfır sayısı pozitif veya negatif bir sayı değildir, nötr bir sayıdır. Pozitif veya negatif olarak değerlendirilemez. Bu sebeple yöntemin bilimsel olarak bir anlam taşıması için nakit akış tablosunu oluşturan işletme, yatırım ve finansman faaliyetlerinden nakit akışlarından herhangi birisi sıfır olan işletme analize dahil edilmemesi gerekmektedir. Türkiye'de muhasebe literatüründe kendisine çokça yer bulmuş olan bu yöntemin kullanıldığı çoğu akademik çalışmada bu hususlar dikkate alınmadığı, dolayısıyla da çalışmalarda hatalara yer verildiği yapılan literatür incelemesi sonucunda gözlemlenmiştir. Analiz sırasında bu hususlar dikkate alınarak veri seti temizlenmiş, nakit akış tablosunda bir ana başlı̆ğ analizin yapıldığı yıllar arasında herhangi bir yıl için sıfır olan işletmeler analiz kapsamı dışında tutulmuştur. Gerekli veri düzenleme işlemi sonucu 171 işletmeden yalnızca 160 işletmenin nakit akış profili yöntemi ile analiz edilmesinin uygun olduğu sonucuna varılmış ve çalışma 160 işletme üzerinde gerçekleştirilmiştir.

İşletmelerin nakit akış bilgileri Kamuyu Aydınlatma Platformu (KAP) üzerinden işletmelerin finansal tabloları ve dipnotları aracılığı ile edinilmiştir. Bu işletmelere ait finansal göstergeler ise FINNNET veri tabanı vasıtasıyla toplanmıştır.

\subsection{Yöntem}

\subsubsection{Finansal Göstergeler}

Çalışma kapsamında nakit akış profillerini karşılaştırmada kullanılan finansal göstergeler Tablo 2'de yer almaktadır. Çalışma kapsamında hesaplanan finansal göstergeler bazı işletmeler için anormal seviyede olduğundan bunlar analizler sırasında temizlenmiştir. İşletmeler için hesaplanan finansal göstergeler ve hesaplanış şekilleri Tablo 2'de yer almaktadir. 
Tablo 2. Finansal Göstergeler

\begin{tabular}{|c|c|c|}
\hline \multicolumn{3}{|c|}{ FİNANSAL GÖSTERGELER } \\
\hline Kisaltma & Tanımı & Hesaplanışı \\
\hline $\mathrm{AB} \%$ & Aktif Büyüme \% & $\begin{array}{c}\text { (Aktif Büyüklüğü t - Aktif Büyüklüğü t-1)/Aktif } \\
\text { Büyüklüğü t-1 }\end{array}$ \\
\hline $\mathrm{PD} / \mathrm{DD}$ & Piyasa Değeri/Defter Değeri & Şirketin Piyasa Değeri/Özkaynakların Defter Değeri \\
\hline $\mathrm{B} / \mathrm{TA}$ & Borç-Toplam Aktif Oranı & Toplam Borç/Toplam Aktif \\
\hline ROA & Aktif Karlılı̆̆1 & Net Kar/Toplam Aktif (Ortalama) \\
\hline ROE & Özkaynak Karlılı̆ğ & Net Kar/Toplam Özkaynak (Ortalama) \\
\hline $\mathrm{CO}$ & Cari Oran & Dönen Varlıklar/Kısa Vadeli Yabancı Kaynaklar \\
\hline LO & Likidite Oranı & $\begin{array}{c}\text { (Dönen Varlıklar-Stoklar)/Kısa Vadeli Yabancı } \\
\text { Kaynaklar }\end{array}$ \\
\hline
\end{tabular}

\subsubsection{TOPSIS Yöntemi}

Chen ve Hwang (1992) tarafindan geliştirilen TOPSİS Yöntemi (Technique for Order Preference by Similarity to An Ideal Solution) Hwang ve Yoon (1981) tarafindan yapılmış olan çalışmalardan türetilmiştir (Demireli, 2010: 102-103). Çok kriterli karar yöntemlerinden bir tanesi olan TOPSIS yöntemi birçok kriteri göz önüne alarak birden fazla alternatif arasında seçim yapmak üzerine kurulmuş bir yöntemdir. Bu yöntem ile alternatif seçeneklerin belirli kriterler ile ve kriterlerin alabileceği maksimum ve minimum değerler arasında ideal duruma göre karşılaştırılması yapılır. Bu yöntem vasıtasıyla nakit akış profili çıkartılan işletmelerin profillere dağıtıldıktan sonra, bu profillerde yer alan işletmelerin ortalama finansal göstergeleri TOPSISS yöntemi vasitasıla tek bir matematiksel ifadeye indirgenecektir. Böylece profillerin birbirine karşı üstünlük dereceleri belirlenecek ve siralamaya tabii tutulabilecektir.

TOPSIS yöntemi 6 adımdan oluşmaktadır (Chen ve Hwang, 1992). Yöntemin ilk aşaması Tablo 1'deki gibi karar matrisinin oluşturulmasıdır. Karar matrisinde, alternatifler (A1..... An ) alt alta sıralanır ve karşılarında her bir kriterin (finansal göstergeler) alternatiflere (Nakit Akış Profillerine) göre gösterdikleri özellikler (Y1k ... Ynk ) listelenir. Yöntemle ilgili diğer hesaplama aşamaları ise aşağıda adım adım belirtilmiştir (Yurdakul ve İç, 2003: s.1113). 
Tablo 3. Karar Matriksi

\begin{tabular}{|c|c|c|c|c|c|}
\hline \multirow{2}{*}{ Alternatifler } & \multicolumn{5}{|c|}{ Kriterler } \\
\cline { 2 - 6 } & $\mathrm{Y} 1$ & $\mathrm{Y} 2$ & $\mathrm{Y3}$ & $\cdots$ & $\mathrm{Yk}$ \\
\hline A1 & $\mathrm{y} 11$ & $\mathrm{y} 12$ & $\mathrm{y} 13$ & $\cdots$ & $\mathrm{y} 1 \mathrm{k}$ \\
\hline A2 & $\mathrm{y} 21$ & $\mathrm{y} 22$ & $\mathrm{y} 23$ & $\cdots$ & $\mathrm{y} 2 \mathrm{k}$ \\
\hline A3 & $\mathrm{y} 31$ & $\mathrm{y} 23$ & $\mathrm{y} 33$ & $\cdots$ & $\mathrm{y} 3 \mathrm{k}$ \\
\hline$\cdots$ & $\cdots$ & $\cdots$ & $\cdots$ & $\cdots$ & $\cdots$ \\
\hline An & $\mathrm{yn} 1$ & $\mathrm{yn} 2$ & $\mathrm{yn} 3$ & $\cdots$ & $\mathrm{ynk}$ \\
\hline
\end{tabular}

1.Adım: Karar matrisindeki kriterlere ait puan veya özelliklerin kareleri toplamının karekökü alınarak matris normalize edilir.

$$
Z_{i j}=\frac{y_{i j}}{\sqrt{\sum_{i=1}^{n} y_{i j}^{2}}} i=1, \ldots \ldots, n ; j=1, \ldots \ldots, k
$$

2. Adım: Normalize edilmiş karar matrisinin elemanları kriterlere verilen önemler doğrultusunda ağırlıklandırılır. Ağırlıklandırma işleminde her kriter için eşit ağırlık kullanılmış (1/6), fakat cari oran ve likidite oranına verilen ağırlık ikiye bölünmüş (1/12), tek bir oran gibi düşünülmüştür.

$$
X_{i j}=w_{j} * z_{i j}
$$

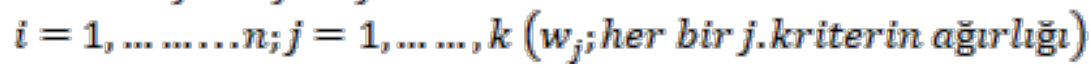

3. Adım: $\mathrm{a}^{+}$ve $\mathrm{a}^{-}$ideal noktaların tanımlanması: Burada ağırlıklı matriste her bir kolonda maksimum ve minimum değerler tespit edilir.

$$
\begin{aligned}
& a^{+}=\left\{X_{1}{ }^{+}, X_{2}{ }^{+}, \ldots X_{k}{ }^{+}\right\} \text {(maksimum değerler) } \\
& a^{-}=\left\{X_{1}{ }^{-}, X_{2}^{-}, \ldots X_{k}{ }^{-}\right\} \text {(minimum değerler) }
\end{aligned}
$$

4. Adım: Maksimum ideal çözüme olan uzaklık aşağıdaki formülle hesaplanır.

$$
S_{i}^{+}=\sqrt{\sum_{j=1}^{k}\left(x_{i j}-x_{j}^{+}\right)^{2}} \quad i=1, \ldots, n
$$


5. Adım: Minimum ideal noktaya olan uzaklık aşağıdaki formülle hesaplanır.

$$
S_{i}^{-}=\sqrt{\sum_{j=1}^{k}\left(x_{i j}-x_{j}^{-}\right)^{2}} \quad i=1, \ldots, n
$$

6. Adım: Her bir alternatifin göreceli sıralaması ve puanı aşağıdaki formül kullanılarak bulunur. En sonda elde edilen $C_{i}$ değerlerine göre sıralama yapılır.

$$
C_{i}=\frac{S_{i}^{-}}{S_{i}{ }^{-}+S_{i}^{+}} \quad i=1, \ldots . . n ; 0 \leq C_{i} \leq 1
$$

\section{ARAŞTIRMANIN BULGULARI}

\section{1. İmalat Sektörü İşletmelerinin Nakit Akış Profilleri}

Çalışma kapsamında ilk olarak pay senetleri BİST'de işlem gören ve nakit akış profili analizine uygun olan 160 imalat sektörü işletmesinin yıllar itibariyle nakit akış profili çıkartılmıştır. İlgili analiz sonucu Şekil 1'de yer almaktadır.

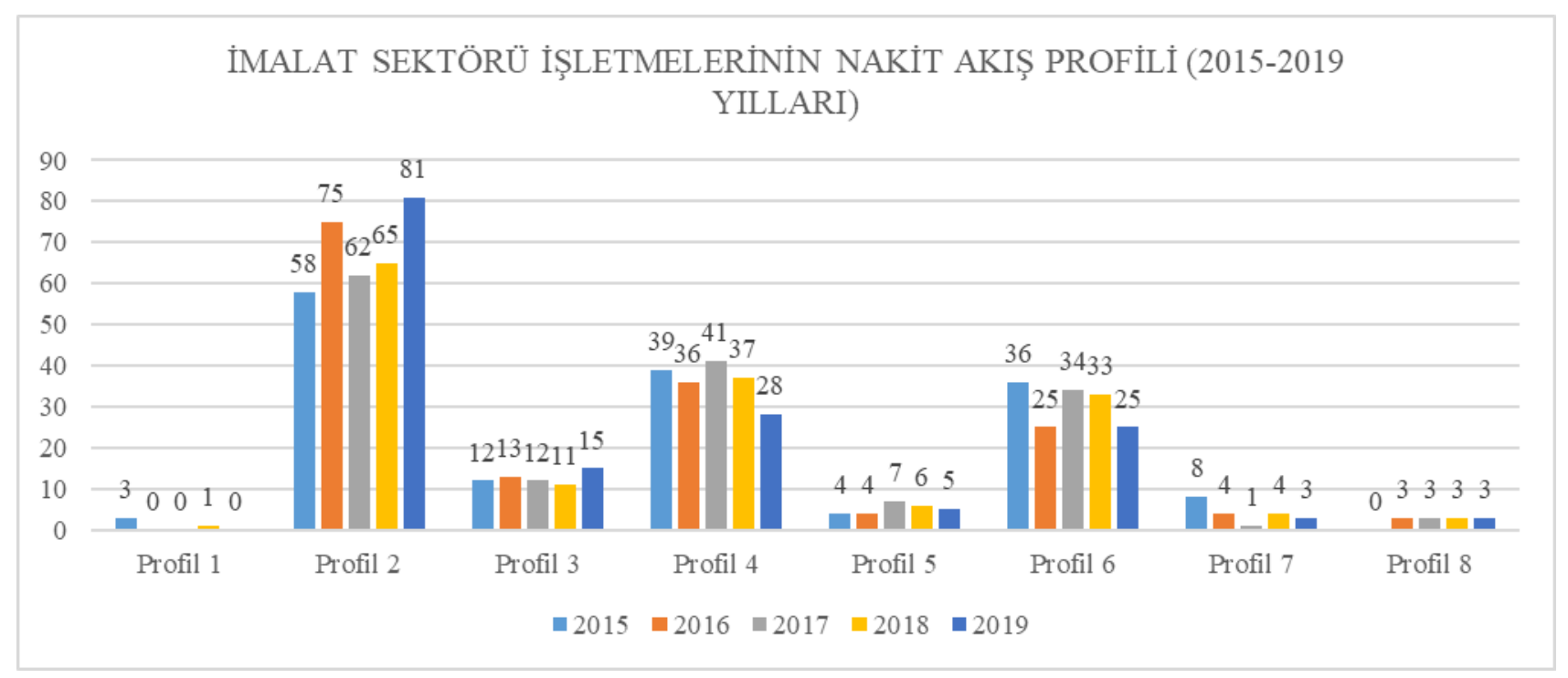

Şekil 1. Şirketlerin Nakit Akış Profilleri

Şekil 1'de görüldüğü üzere, BİST'de kayıtlı şirketlerin büyük çoğunluğu başarılı işletme (profil 2) grubuna girmektedir. Başarılı işletme grubundaki şirket sayısı yıllar itibariyle artmıştır. İkinci en dominant grup ise büyüyen işletmelerdir (profil 4). Fakat bu profildeki işletmelerin sayıları yıllar itibariyle ciddi oranda azalmıştır. Üçüncü en büyük grup ise genç işletme (profil 6) grubudur. Bu işletmelerin sayısı da büyüyen işletmeler gibi yıllar itibariyle azalsa da hala toplam içerisinde önemli bir paya sahiptir. Gerileyen veya yeniden yapılanan işletmelerin (profil 3) sayısı yıllar itibariyle artış göstermiştir. Profil 4 ve profil 6'daki azalışın yıllar itibariye bu gruba ve profil 2'ye kaydığı söylenebilir. Nadir durum olarak adlandırılan profil $1(+,+,+)$ ve profil $8(-,-,-)$ grubundaki işletmelerin ciddi oranda 
az olduğu görülmektedir. Analiz edilen işletmelerden nakit akışları anormal bir görüntü oluşan şirketler az yer kaplamaktadır. Likiditasyona giden işletme (profil 7) sayısı iki yıl azalsa da aynı seviyelerde kalmıştır. Son olarak, küçülen işletme (profil 5) grubunda yer alan şirket sayısı ise diğer profillere nazaran oldukça azdır.

İmalat sektörüne bakıldığında; başarılı, büyüyen ve genç işletmelerin baskın olduğu görülmektedir. 2015 Yılında imalat sektörü işletmelerinin \%36'sı başarılı iken 2019 yılında bu oran \%50'ye kadar çıkmıştır. Gerileyen işletmeler zamanla artmış fakat toplam içerisindeki payı \%9,1'i aşacak seviyeye ulaşmamıştır. Büyüyen ve genç işletmeler zamanla azalmış, bu profildeki işletmeler ise başarılı işletme kategorisine kaymıştır.

\subsection{TOPSIS Yöntemi ile Profillerin Karşılaştırılması}

Çalışmaya konu olan işletmelere ait finansal göstergeler araştırmanın yapıldığı beş yıl için hesaplanmıştır. Hesaplanan finansal oranlar, işletmelerin ait oldukları nakit akış profiline göre gruplandırılmış ve her profil için finansal göstergelerin ortalama değerleri hesaplanmıştır. Bahsi geçen değerler Tablo 6'da verilmiştir. Bu finansal göstergeler aynı zamanda TOPSIS yöntemi için girdileri, karar matrislerini, oluşturmaktadır. İlk sütunda sekiz adet işletme profili yer almaktadır. Her profil TOPSIS yöntemi için bir alternatif niteliğindedir. Analizin sonucunda profiller elde edilen üstünlük derecelerine göre siralanacaktır.

Her yıla ait karar matrisinin 4. satırı finansal göstergenin adını taşımakta ve altında yer alan hücrelerde ise her profile ait ortalama finansal oran yer almaktadır. $\mathrm{Bu}$ finansal göstergeler kullanılan yöntem için karar kriteridir. TOPSIS yöntemi bu kriterlerin tamamını eş zamanlı olarak dikkate alan ve alternatifleri en iyiden en kötüye kadar sıralayan bir yöntemdir.

Her yılın altındaki "Faydalı- Faydalı Değil" ibaresi, 4. satırda yer alan finansal göstergenin analiz için hangi nitelikte olduğunu simgelemektedir. Başarıyı tanımlarken "Faydalı" ibaresi olan finansal göstergelerin maksimum, "Faydalı Değil" ibaresi olanların ise minimum olması istenmektedir.

Her yıl tablosunun 3. satırı en iyi profili bulmada kullanılan finansal göstergelere verilen önem ağırlıklarıdır. Cari oran ve likidite (asit test) oranları haricindeki oranlara eşit ağırlık (1/6) verilmiştir. Bahsi geçen iki oran ise tek bir kriter olarak değerlendirilmesi istendiği için, önem ağırlıklarının toplamları tek bir finansal göstergenin ağırlığına eşit olacak şekilde ikiye bölünmüş, 1/12 önem ağırlığg verilmiştir.

Nakit akış profillerinin TOPSIS yöntemi ile analizi çalışma kapsamındaki her yıl için birbirinden bağımsız olarak yapılmıştır. 
Tablo 4. Nakit Akış Profillerine Ait Finansal Göstergeler

\begin{tabular}{|c|c|c|c|c|c|c|c|}
\hline \multicolumn{8}{|c|}{2015 YILI FINANSAL ORANLAR-TOPSIS KARAR MATRİSI } \\
\hline & Faydal1 & Faydal1 & Faydalı Değil & Faydal1 & Faydalı & Faydal1 & Faydali \\
\hline \multirow[t]{2}{*}{ Ăğırlıklar } & 0,167 & 0,167 & 0,167 & 0,167 & 0,167 & 0,083 & 0,083 \\
\hline & AB \% & PD/DD & B/TA & ROA & ROE & CO & LO \\
\hline Profil 1 & 0,186 & 1,277 & 0,463 & 0,086 & 0,145 & 1,737 & 1,107 \\
\hline Profil 2 & 0,142 & 2,144 & 0,463 & 0,059 & 0,092 & 2,088 & 1,337 \\
\hline Profil 3 & 0,100 & 1,496 & 0,548 & 0,035 & 0,038 & 1,761 & 1,193 \\
\hline Profil 4 & 0,277 & 1,884 & 0,503 & 0,048 & 0,097 & 1,929 & 1,351 \\
\hline Profil 5 & 0,166 & 1,118 & 0,578 & 0,053 & 0,102 & 1,960 & 1,320 \\
\hline Profil 6 & 0,207 & 1,826 & 0,594 & $-0,003$ & $-0,012$ & 1,377 & 0,904 \\
\hline Profil 7 & 0,055 & 3,280 & 0,509 & 0,013 & 0,039 & 2,171 & 1,093 \\
\hline Profil 8 & - & - & - & - & - & - & - \\
\hline \multicolumn{8}{|c|}{2016 YILI FINANSAL ORANLAR-TOPSISS KARAR MATRİSI } \\
\hline & Faydalı & Faydalı & Faydalı Değil & Faydal1 & Faydalı & Faydalı & Faydal1 \\
\hline \multirow[t]{2}{*}{ Ăğırlıklar } & 0,167 & 0,167 & 0,167 & 0,167 & 0,167 & 0,083 & 0,083 \\
\hline & AB \% & PD/DD & B/TA & ROA & ROE & $\mathrm{CO}$ & LO \\
\hline Profil 1 & - & - & - & - & - & - & - \\
\hline Profil 2 & 0,096 & 1,974 & 0,480 & 0,041 & 0,071 & 1,952 & 1,273 \\
\hline Profil 3 & $-0,031$ & 1,699 & 0,614 & 0,011 & $-0,048$ & 1,266 & 0,889 \\
\hline Profil 4 & 0,184 & 1,752 & 0,547 & 0,038 & 0,067 & 1,728 & 1,115 \\
\hline Profil 5 & 0,126 & 1,330 & 0,512 & $-0,020$ & $-0,049$ & 1,495 & 0,770 \\
\hline Profil 6 & 0,180 & 1,653 & 0,619 & 0,010 & $-0,009$ & 1,500 & 1,056 \\
\hline Profil 7 & $-0,050$ & 5,903 & 0,674 & $-0,036$ & $-0,239$ & 1,220 & 0,675 \\
\hline Profil 8 & 0,054 & 4,043 & 0,475 & $-0,003$ & 0,001 & 1,000 & 0,523 \\
\hline \multicolumn{8}{|c|}{2017 YILI FİNANSAL ORANLAR-TOPSİS KARAR MATRİİ } \\
\hline & Faydalı & Faydalı & Faydalı Değil & Faydal1 & Faydalı & Faydalı & Faydal1 \\
\hline \multirow[t]{2}{*}{ Ăğırlıklar } & 0,167 & 0,167 & 0,167 & 0,167 & 0,167 & 0,083 & 0,083 \\
\hline & AB \% & PD/DD & B/TA & ROA & ROE & CO & LO \\
\hline Profil 1 & - & - & - & - & - & - & - \\
\hline Profil 2 & 0,164 & 2,419 & 0,496 & 0,071 & 0,164 & 1,798 & 1,154 \\
\hline Profil 3 & 0,152 & 1,418 & 0,566 & 0,019 & 0,037 & 1,485 & 0,897 \\
\hline Profil 4 & 0,230 & 1,841 & 0,562 & 0,049 & 0,116 & 1,668 & 1,132 \\
\hline Profil 5 & 0,251 & 2,761 & 0,644 & 0,035 & 0,073 & 1,472 & 0,868 \\
\hline Profil 6 & 0,246 & 2,150 & 0,619 & 0,020 & 0,035 & 1,332 & 0,928 \\
\hline Profil 7 & 0,037 & 0,950 & 0,345 & $-0,001$ & $-0,002$ & 3,590 & 2,370 \\
\hline Profil 8 & 0,034 & 2,167 & 0,535 & 0,025 & 0,063 & 1,757 & 1,427 \\
\hline \multicolumn{8}{|c|}{2018 YILI FINAANSAL ORANLAR-TOPSİS KARAR MATRISİ } \\
\hline & Faydalı & Faydalı & Faydalı Değil & Faydal1 & Faydalı & Faydalı & Faydali \\
\hline \multirow[t]{2}{*}{ Ăğırlıklar } & 0,167 & 0,167 & 0,167 & 0,167 & 0,167 & 0,083 & 0,083 \\
\hline & AB \% & PD/DD & B/TA & ROA & ROE & CO & LO \\
\hline Profil 1 & - & - & - & - & - & - & - \\
\hline
\end{tabular}




\begin{tabular}{|c|c|c|c|c|c|c|c|}
\hline Profil 2 & 0,171 & 1,549 & 0,508 & 0,074 & 0,161 & 1,774 & 1,127 \\
\hline Profil 3 & 0,091 & 1,549 & 0,596 & 0,077 & 0,196 & 1,936 & 1,338 \\
\hline Profil 4 & 0,343 & 1,325 & 0,611 & 0,058 & 0,154 & 1,466 & 0,885 \\
\hline Profil 5 & 0,042 & 1,250 & 0,519 & 0,025 & 0,030 & 1,343 & 1,057 \\
\hline Profil 6 & 0,229 & 1,431 & 0,592 & 0,001 & $-0,033$ & 1,468 & 0,856 \\
\hline Profil 7 & $-0,038$ & 4,317 & 0,716 & $-0,083$ & 0,028 & 1,550 & 0,780 \\
\hline Profil 8 & 0,098 & 1,593 & 0,299 & 0,076 & 0,092 & 3,830 & 1,755 \\
\hline \multicolumn{8}{|c|}{2019 YILI FİNANSAL ORANLAR-TOPSİS KARAR MATRİSI } \\
\hline & Faydal1 & Faydalı & Faydalı Değil & Faydalı & Faydal1 & Faydal1 & Faydal1 \\
\hline \multirow[t]{2}{*}{ A ğırlıklar } & 0,167 & 0,167 & 0,167 & 0,167 & 0,167 & 0,083 & 0,083 \\
\hline & AB \% & PD/DD & B/TA & ROA & ROE & CO & LO \\
\hline Profil 1 & - & - & - & - & - & - & - \\
\hline Profil 2 & 0,125 & 2,530 & 0,552 & 0,041 & 0,096 & 1,690 & 1,111 \\
\hline Profil 3 & 0,094 & 2,477 & 0,537 & 0,042 & 0,082 & 1,932 & 1,291 \\
\hline Profil 4 & 0,217 & 2,032 & 0,624 & 0,049 & 0,103 & 1,566 & 1,128 \\
\hline Profil 5 & 0,151 & 2,092 & 0,612 & $-0,002$ & $-0,066$ & 1,096 & 0,805 \\
\hline Profil 6 & 0,187 & 1,857 & 0,578 & $-0,005$ & $-0,037$ & 1,766 & 1,030 \\
\hline Profil 7 & 0,070 & 2,570 & 0,457 & 0,035 & $-0,049$ & 3,425 & 0,750 \\
\hline Profil 8 & 0,123 & 4,657 & 0,562 & 0,025 & 0,056 & 1,567 & 0,850 \\
\hline
\end{tabular}

Tablo 4'de yer alan karar matrisleri üzerinde Bölüm 3.3.3.'te anlatılan adımlar izlenerek her yıl için analizler yapılmıştır. Karar matrisleri üzerinde öncelikle normalize matris oluşturma işlemi gerçekleştirilmiştir. 2019 Yılına ait normalize edilmiş karar matrisi Tablo 5'de verilmiştir.

Tablo 5. Normalize Edilmiş Karar Matrisi (2019 Y1lı)

\begin{tabular}{|c|c|c|c|c|c|c|c|}
\cline { 2 - 8 } \multicolumn{1}{c|}{} & AB \% & PD/DD & B/TA & ROA & ROE & CO & LO \\
\hline & & & & & & & \\
\hline Profil 2 & 0,324 & 0,348 & 0,371 & 0,461 & 0,491 & 0,322 & 0,415 \\
\hline Profil 3 & 0,243 & 0,341 & 0,361 & 0,479 & 0,424 & 0,368 & 0,482 \\
\hline Profil 4 & 0,562 & 0,280 & 0,419 & 0,557 & 0,531 & 0,298 & 0,421 \\
\hline Profil 5 & 0,390 & 0,288 & 0,411 & $-0,024$ & $-0,340$ & 0,209 & 0,301 \\
\hline Profil 6 & 0,483 & 0,256 & 0,388 & $-0,062$ & $-0,189$ & 0,336 & 0,385 \\
\hline Profil 7 & 0,181 & 0,354 & 0,307 & 0,402 & $-0,253$ & 0,653 & 0,280 \\
\hline Profil 8 & 0,318 & 0,641 & 0,378 & 0,286 & 0,286 & 0,299 & 0,318 \\
\hline
\end{tabular}

TOPSIS yönteminin uygulanmasında normalize edilmiş karar matrisinin oluşturulmasından sonraki adım ise ağırlıklandırma işlemidir. Bu aşamada normalize edilmiş karar matrisinin her bir elemanı belirlenmiş olan önem ağırlıklarıyla çarpılarak ağırlıklandırılmıştır. 2019 Yılına ait ağırlıklandırılmış karar matrisi Tablo 6'da verilmiştir. 
Tablo 6. Ağırlıklandırılmış Karar Matrisi (2019 Yı1ı)

\begin{tabular}{|c|c|c|c|c|c|c|c|}
\cline { 2 - 8 } \multicolumn{1}{c|}{} & AB \% & PD/DD & B/TA & ROA & ROE & CO & LO \\
\hline & & & & & & & \\
\hline Profil 2 & 0,054 & 0,058 & 0,062 & 0,077 & 0,082 & 0,027 & 0,035 \\
\hline Profil 3 & 0,040 & 0,057 & 0,060 & 0,080 & 0,071 & 0,031 & 0,040 \\
\hline Profil 4 & 0,094 & 0,047 & 0,070 & 0,093 & 0,089 & 0,025 & 0,035 \\
\hline Profil 5 & 0,065 & 0,048 & 0,069 & $-0,004$ & $-0,057$ & 0,017 & 0,025 \\
\hline Profil 6 & 0,081 & 0,043 & 0,065 & $-0,010$ & $-0,031$ & 0,028 & 0,032 \\
\hline Profil 7 & 0,030 & 0,059 & 0,051 & 0,067 & $-0,042$ & 0,054 & 0,023 \\
\hline Profil 8 & 0,053 & 0,107 & 0,063 & 0,048 & 0,048 & 0,025 & 0,026 \\
\hline
\end{tabular}

Yukarıdaki işlemden sonraki adımda ise ağırlıklandırılmış karar matrisi tablosu (Tablo 6) üzerinden her bir kolonun (karar kriterinin) maksimum ve minimum değerleri tespit edilmiştir. "Faydalı Değil” tanımlamasına sahip "Borç/ Toplam Aktif” oranı için ise işlem ters yapılmış, $\mathrm{a}^{+}$değeri olarak en küçük, $\mathrm{a}^{-}$değeri için ise en büyük değer aranması yönteme uygulanmıştır. 2019 Yılına ait pozitif ideal ve negatif ideal çözüm noktaları Tablo 7'de verilmiştir.

Tablo 7. Maksimum ve Minimum İdeal Çözüm Noktaları

\begin{tabular}{|c|c|c|c|c|c|c|c|}
\cline { 2 - 7 } \multicolumn{1}{c|}{} & AB \% & PD/DD & B/TA & ROA & ROE & CO & LO \\
\hline $\mathrm{a}^{+}$ & 0,094 & 0,107 & 0,051 & 0,093 & 0,089 & 0,054 & 0,040 \\
\hline $\mathrm{a}^{-}$ & 0,030 & 0,043 & 0,070 & $-0,010$ & $-0,057$ & 0,017 & 0,023 \\
\hline
\end{tabular}

Daha sonrasinda her bir alternatifin maksimum ve minimum ideal noktalara ( $\mathrm{a}^{+}$ve $\left.\mathrm{a}^{-}\right)$ olan uzaklıkları $\left(\mathrm{S}^{+}\right.$ve $\mathrm{S}^{-}$) hesaplanmıştır. Son olarak her alternatif (profil) için $\mathrm{C}_{\mathrm{i}}$ değeri hesaplanarak göreceli sıralaması yapılmıştır. Analizin yapıldığı her yıl için nakit akış profillerinin maksimum ve minimum noktalara olan uzaklıkları ve görece üstünlük puanlarıyla sıralamaları Tablo 8'de verilmiştir. 2015 Yılında profil 8; 2016, 2017 ve 2019 yıllarında ise profil 1 kategorisine giren işletme bulunmamaktadır. İlgili yıllarda bu profilleri gösteren işletme bulunmaması sebebiyle analize dahil edilememişlerdir. Bu duruma ek olarak 2018 y1lında profil 1'de yalnızca 1 işletme bulunmaktadır. Bu işletmenin finansal göstergeleri aykırı gözlem değeri içerdiğinden analiz dışı bırakılmış, dolayısıyla 2018 yılında da profil 1 analiz edilememiştir.

Tablo 8. TOPSIS Yöntemi Sonuçları

\begin{tabular}{|c|c|c|c|c|c|}
\hline \multicolumn{7}{|c|}{ TOPSIS ÇIKTILARI (Si+, Si-, Ci, SIralamalar) } \\
\hline Yıllar & Alternatifler & Si+ $^{+}$ & Si- & Ci & Başarı Siralaması \\
\hline \multirow{4}{*}{2015} & Profil 1 & 0,073 & 0,168 & 0,698 & 1 \\
\cline { 2 - 6 } & Profil 2 & 0,079 & 0,120 & 0,602 & 3 \\
\cline { 2 - 6 } & Profil 3 & 0,133 & 0,064 & 0,326 & 6 \\
\cline { 2 - 6 } & Profil 4 & 0,075 & 0,133 & 0,641 & 2 \\
\cline { 2 - 6 } & Profil 5 & 0,096 & 0,117 & 0,549 & 4 \\
\cline { 2 - 6 } & Profil 6 & 0,170 & 0,059 & 0,258 & 7 \\
\hline
\end{tabular}


Muhasebe ve Finansman Dergisi - Nisan 2021

(90): 127-148

\begin{tabular}{|c|c|c|c|c|c|}
\hline & Profil 7 & 0,145 & 0,083 & 0,363 & 5 \\
\hline & Profil 8 & - & - & - & - \\
\hline \multirow{8}{*}{2016} & Profil 1 & - & - & - & - \\
\hline & Profil 2 & 0,094 & 0,279 & 0,749 & 2 \\
\hline & Profil 3 & 0,179 & 0,163 & 0,477 & 5 \\
\hline & Profil 4 & 0,087 & 0,288 & 0,769 & 1 \\
\hline & Profil 5 & 0,191 & 0,157 & 0,452 & 6 \\
\hline & Profil 6 & 0,126 & 0,219 & 0,634 & 3 \\
\hline & Profil 7 & 0,295 & 0,094 & 0,242 & 7 \\
\hline & Profil 8 & 0,141 & 0,188 & 0,570 & 4 \\
\hline \multirow{8}{*}{2017} & Profil 1 & - & - & - & - \\
\hline & Profil 2 & 0,054 & 0,183 & 0,771 & 1 \\
\hline & Profil 3 & 0,148 & 0,063 & 0,298 & 6 \\
\hline & Profil 4 & 0,076 & 0,141 & 0,649 & 2 \\
\hline & Profil 5 & 0,107 & 0,125 & 0,539 & 3 \\
\hline & Profil 6 & 0,141 & 0,094 & 0,400 & 4 \\
\hline & Profil 7 & 0,194 & 0,061 & 0,238 & 7 \\
\hline & Profil 8 & 0,139 & 0,077 & 0,356 & 5 \\
\hline \multirow{8}{*}{2018} & Profil 1 & - & - & - & - \\
\hline & Profil 2 & 0,112 & 0,203 & 0,644 & 2 \\
\hline & Profil 3 & 0,130 & 0,207 & 0,615 & 3 \\
\hline & Profil 4 & 0,109 & 0,219 & 0,668 & 1 \\
\hline & Profil 5 & 0,180 & 0,118 & 0,396 & 6 \\
\hline & Profil 6 & 0,180 & 0,128 & 0,416 & 5 \\
\hline & Profil 7 & 0,236 & 0,097 & 0,291 & 7 \\
\hline & Profil 8 & 0,131 & 0,190 & 0,593 & 4 \\
\hline \multirow{8}{*}{2019} & Profil 1 & - & - & - & - \\
\hline & Profil 2 & 0,072 & 0,167 & 0,699 & 2 \\
\hline & Profil 3 & 0,080 & 0,159 & 0,664 & 3 \\
\hline & Profil 4 & 0,070 & 0,190 & 0,731 & 1 \\
\hline & Profil 5 & 0,191 & 0,036 & 0,158 & 7 \\
\hline & Profil 6 & 0,174 & 0,058 & 0,251 & 6 \\
\hline & Profil 7 & 0,156 & 0,090 & 0,367 & 5 \\
\hline & Profil 8 & 0,081 & 0,138 & 0,630 & 4 \\
\hline
\end{tabular}


2015 yılında en iyi finansal performansı gösteren profiller sırasıyla nadir durum $(+,+$, + ), büyüyen işletme $(+,-,+)$ ve başarılı işletme $(+,-,-)$ profilleri olmuştur. En kötü performans sergileyen profiller ise genç işletme $(-,-,+)$, gerileyen ve yeniden yapılanmaya giden işletme $(+,+,-)$ ve likiditasyona giden işletme $(-,+,-)$ profilleridir.

2016 yılına bakıldığında büyüyen işletme $(+,-,+)$, başarılı işletme $(+,-,-)$ ve genç işletme $(-,-,+)$ profilleri tüm profiller arasında sırasıyla en başarılı olanlardır. En kötü performans gösteren profiller ise likiditasyona giden işletme, küçülen işletme $(-,+,+)$ ve gerileyen veya yeniden yapılanmaya giden işletme profilleri olmuştur.

2017 yılına gelindiğinde ise en başarılı işletme profili ilk kez başarılı işletme (+, -, -) profili olmuş, diğer tüm profillerin üzerinde performans göstermiştir. Onu izleyen diğer başarılı profiller ise büyüyen işletme $(+,-,+)$ ve küçülen işletme $(-,+,+)$ profilleridir. Bu yıl özelinde en kötü performansı likiditasyona giden işletme $(-,+,-)$, gerileyen ve yeniden yapılanmaya giden işletme $(+,+,-)$ ve nadir durum $(-,-,-)$ profilleri göstermiştir.

2018 yılında en iyi performansı büyüyen işletme profilindeki şirketler gerçekleştirmiştir. Onu takiben ise başarılı işletme ve gerileyen veya yeniden yapılanmaya giden işletme profilleri gelmektedir. $\mathrm{Bu}$ yılda en kötü performansı ise likiditasyona giden işletme, küçülen işletme $(-,+,+)$ ve genç işletme $(-,-,++)$ profilleri göstermektedir.

2019 yılında en iyi performansı gösteren profiller sırasıyla büyüyen işletme, başarılı işletme ve gerileyen ve yeniden yapılanmaya giden işletme profilleridir. En kötü performansı ise, küçülen işletme, genç işletme ve likiditasyona giden işletme profilleri göstermektedir.

\section{SONUÇ VE TARTIŞMA}

Nakit yönetiminin finansal yönetimin ayrılmaz bir parçası haline geldiği günümüz dünyasında nakit akışlarının doğru bir şekilde anlaşılmasının ve yönetilmesinin işletme yöneticileri açısından önemi her geçen gün artmaktadır. Finansal bilgi kullanıcıları açısından ise nakit akışları işletmelerin analizinde ve durumunun değerlendirilmesinde yeni bir bakış açısı sunmaktadır.

Nakit akış bilgilerinin sunulduğu nakit akış tablosu diğer önemli finansal tablolar olan finansal durum tablosu ve kapsaml gelir tablosundan yer almayan belirli, spesifik bilgileri sağlaması açısından önemlilik arz etmekte, işletmelerin gelecek performansının tahmininde önemli bir yer tutmaktadır.

$\mathrm{Bu}$ çalışmada nakit akış tablolarının analizi için literatürde en çok kullanılan yöntemlerden birisi olan "Nakit Akış Profilì" yöntemi kullanılarak pay senetleri BİST'de işlem gören imalat sektörü işletmeleri analiz edilmiştir. Yapılan analiz sonucunda ülkemizde imalat sektörü işletmelerin büyük çoğunluğunun başarılı işletme (profil 2), büyüyen işletme (profil 4) ve genç işletme (profil 6) gruplarında kümelendiği sonucuna ulaşılmıştır. Ulaşılan sonuçlar; Orhan ve Başar (2015), Karadeniz ve diğ. (2018) ve Tükeçi ve Karaca (2019) ile uyuşmakta, Aktaş ve diğ. (2012) ve Karadeniz (2017) ile kısmen uyuşmaktadır.

Çalışmanın ikinci kısmında elde edilen nakit akış profillerinin finansal performans göstergeleri hesaplanmış ve TOPSIS yöntemi kullanılarak profiller başarı sıralamasına 
tutulmuştur. Finansal performans göstergesi olarak "Aktif Büyümesi, Piyasa Değeri/Defter Değeri, Borç/Toplam Aktif, Aktif Karlılığı, Özkaynak Karlılığı, Cari Oran ve Likidite Oranı” kullanılmıştır.

Yapılan çalışma sonucunda başarılı işletme (profil 2) profili yalnızca bir yılda en başarılı performansı sergilemiştir. Analizin yapıldığı beş yıl içerisinde tüm profiller arasında üç yıl ikinci sırada, bir yıl ise üçüncü sırada yer almıştır. Sonuç olarak başarılı işletme profili her yıl en başarılı işletme olamamıştır.

Gerileyen ve yeniden yapılanmaya giden işletme (profil 3) profili ilk üç yılda beklendiği gibi başarı sıralamasında aşağılarda, altıncı sırada yer almıştır. Fakat son iki yılda en başarılı ilk 3 işletme profili arasında yer almaktadır.

Büyüyen işletme (profil 4) profili beş yıllık periyot içerisinde üç yıl birinci sırada yer alarak başarılı işletme profilinden bile daha başarılı olmuştur.

Likiditasyona giden işletme (profil 7) profili ise beklendiği gibi başarı sıralamasında diğer profillerin altında kalmış, üç yıl artarda en son sırada yer almıştır. Diğer iki yılda ise alt sıralarda başarı göstermiştir.

Küçülen işletme (profil 5) ve genç işletme (profil 6) profillerinin başarı sıralamaları ise düzensiz bir yol izlemektedirler.

Çalışmada "Nakit Akış Profili"” yöntemine göre oluşturulan işletme profillerinin finansal performansları TOPSIS yöntemiyle analiz edildiğinde, nakit akış profillerinin finansal performans sıralaması sonucunda başarılı işletme kabul edilen profilin kullanılan finansal performans girdileri ve yöntem itibariyle en yüksek başarıyı göstermediği, en yüksek başarıyı gösteren işletme profilinin büyüyen işletme profili olduğu sonucuna varılmıştır. Finansal performans sıralaması düşük olması beklenen gerileyen ve yeniden yapılanmaya giden işletme profili ise başarı sıralamasında ilk 3 içerisinde yer almıştır. Genel olarak bakıldığında "Nakit Akış Profilil" yönteminin her zaman başarılı bir sonuç verdiği söylenememektedir. Bunun sebebi ise kullanılan yöntemin temelinde yatmaktadır. Gup ve diğ. (1993) tarafından geliştirilen bu yöntemin en önemli sorunu nakit akışlarının sağlandığı faaliyetlerin büyüklüğünü dikkate almaması, yalnızca işaretleri ile ilgilenmesidir. Yöntem nakit akışlarının sağlandığı faaliyetlerin büyüklük tutarlarının işletmeler arasında ciddi farklar gösteriyor olsa bile işaretleri aynı olması sebebiyle aynı muameleyi göstermekte, aynı profil altında gruplamaktadır. İşletmelerin en önemli finansal tablolarından birisi olan nakit akış tablosunun analizinde Gup ve diğ. (1993) tarafindan ortaya konulan bu yöntemin eksikliğini giderecek yeni bir yöntem geliştirilmesi muhasebe ve finans literatürüne katkı sağlayacaktır.

$\mathrm{Bu}$ çalışmada yalnızca imalat sektöründe faaliyet gösteren işletmeler incelenmiştir. İleride yapılacak çalışmalarda farklı sektörler incelendiğinde sonucun değişmesi muhtemeldir. Buna ek olarak bu çalışmada 2015-2019 yılları arası incelenmiştir. Daha uzun bir periyot seçilmesi durumunda sonuçlar değişiklik gösterebilir. 


\section{KAYNAKLAR}

Aktaş, R. - Karğın, S.- Karğın, M. (2012), "Nakit Akışlarının Sağlandığı Faaliyetler Yöntemi ile İşletmelerin Nakit Akış Profillerinin İncelenmesi", Muhasebe ve Finansman Dergisi, (56),ss. 101-118.

Baskan, T.D. - Dozen, B. (2019), “Türkiye Muhasebe Standartlarına Göre İşletmelerin Nakit Akış Profillerinin BİST 100 Endeksi Üzerinde Analizi”, İşletme Araştırmaları Dergisi, 11(4), ss.3347-3357.

Beyazgül, M. - Karadeniz, E., (2019), "Futbol Kulüplerinin Nakit Akış Profillerinin Analizi: Uluslararası Bir Karşılaştırma”, Muhasebe ve Vergi Uygulamaları Dergisi, 12(3), ss.605-624

Bruwer, S. - Hamman, W.D. (2005), "Cash Flow Patterns in Listed South African Industrial Companies”, Meditari Accountancy Research,13(1), pp.1-17.

Cavlak, H. - Yılmaz, C. (2020), "Nakit Akış Yapısı-İşletme Yaşam Döngüsü ile Finansal Sıkıntının Birlikte Değerlendirilmesi: BIST Sürdürülebilirlik Endeksi'nde Bir Araştırma", Journal of Yasar University, 15(60), ss.806-832.

Demireli, E., (2010), “TOPSİS Çok Kriterli Karar Verme Sistemi, Türkiye’deki Kamu Bankaları Üzerine Bir Uygulama”, Girişimcilik ve Kalkınma Dergisi, 5(1), ss.101112.

Dickinson, V. (2011), "Cash Flow Patterns As A Proxy For Firm Life Cycle”, The Accounting Review; 86(6), pp. 1969-994.

Gup, B.E. - Samson, W.D. - Dugan, M.T.- Kim, M.J.- Jittrapanun, T. (1993), “An Analysis of Patterns from the Statement of Cash Flows”, Financial Practice and Education, pp.7379.

Güleç, Ö.F. - Arda, I., (2019), “Investigation of Cash Flow Profiles: Evidence From Turkey”, Muhasebe ve Finansman Dergisi, Ağustos 2019 Özel Say1, pp. 555-568

Kablan, A. - Güvemli, B., (2019), "Cash Flow Profiles of Tourism Companies at Borsa Istanbul”, Muhasebe ve Finansman Dergisi, Ağustos 2019 Özel Sayı, pp.235-246.

Kablan, A. - Altun, S. (2020), "Belediyelerde Nakit Akıș Tablolarının Kullanımına Yönelik Bir Araştırma ve Nakit Akış Tablosu Analiz Teknikler Üzerine Bir Uygulama”, Muhasebe Enstitüsü Dergisi, 63, ss.33-52.

Karadeniz, E., (2017), "Halka Açık Konaklama İşletmelerinin Nakit Akış Profillerinin Analizi: Uluslararası Bir Karşılaştırma”, Seyahat ve Otel İşletmeciliği Dergisi, 14(3), ss. $167-185$ 
Karadeniz, E. - Günay, F.- Dalak, S. - Beyazgül, M., (2018), "Halka Açık Restoran İşletmelerinde Nakit Akış Profillerinin Firma Yaşam Döngüsü Açısından İncelenmesi: Uluslararası Bir Karşılaştırma”, Ç.Ü. Sosyal Bilimler Enstitüsü Dergisi, 1(27), ss.139156

Karğın, M. - Aktaş, R. (2011), "Türkiye Muhasebe Standartlarına Göre Raporlanmış Nakit Akış Tablosu ve Analizi”, Muhasebe ve Finansman Dergisi.52. ss 1-24.

Kepçe, N. (2017), “Can We Evaluate Economic Features of Companies by Using Cash Flow Information In a Different Way? Evidence from Turkish Manufacturing Industry”, Bankacılık ve Finansal Araştırmalar Dergisi, 4(2), pp.62-69.

Largay, J.A. - Stickney, C.P. (1980), "Cash Flows, Ratio Analysis and the W.T. Grant Company Bankruptcy”, Financial Analysts Journal,36(4), pp.51-54.

Orhan, A. - Başar, B. (2015), "İşletmelerde Nakit Akış Profilleri ve Analizi: Bist 100 İşletmeleri Üzerine Bir Uygulama", Muhasebe ve Vergi Uygulamaları Dergisi, 8(2), ss.107-121.

Tüfekçi, B. - Karaca, S. S., (2019), "İşletmelerin Nakit Akış Profillerinin Analizi: Uluslararası Bir Karşılaştırma", Sosyal Bilimler Araştırmaları Dergisi, Ekonomi ve Siyaset Özel Sayıs1, ss.157-180 
